Jap. J. M. Sc. \& Biol., 12, 79-97, 1959

\title{
THE DEVELOPMENT OF VARIANTS OF HELA CELLS POSSESSING RESISTANCE AGAINST THE CYTOPATHOGENIC EFFECT OF ECHO VIRUSES
}

\author{
MINORU NAKANO \\ Department of Virology \& Rickettsiology, National Institute of Health, Tokyo
}

(Received: April 29th, 1959)

Experiences in the tissue culture of animal cells have indicated that prolonged serial passage of cells can be a cause for the occurrence of variation in the cellular morphology, malignancy and nutritional requirements (Sanford et al., 1954 ; Earle and Nettleship, 1943 ; Goldblatt and Cameron, 1953 ; Sanford et al., 1950 ; Chang, 1957; Haff and Swimm, 1957; Perry et al., 1955; Puck and Fischer, 1956). In the field of virology, it has attracted attention that the properties of cells subject to such variation include the spectrum of viruses to which they are susceptible. Bang et al. (1952) reported that the variation which occurred in a stable cell line of normal rat fibroblast, $14 \mathrm{p}$, altered not only its malignancy but also its susceptibility to eastern equine encephalitis virus. A recent finding by Sheffield (1957) revealed that the changes of rabbit embryo kidney cells after a serial cultivation in vitro rendered them susceptible to polioviruses.

The widespread use of strain HeLa cells (Gey et al., 1952) has led to the finding that there exist cell lines with different abilities to propagate viruses. Scherer (1955) demonstrated that the HeLa strain supplied from "Microbiological Associates " differed from an original line of HeLa cells in their cytologic responses to polioviruses. A similar note was made in studies on adenovirus about different susceptibilities to viruses among HeLa cell lines used (Graystone et al., 1958). The HeLa cell strain employed by Quersin-Thiry (1958) was inferior to the one used by Lennox et al. (1957) in susceptibility to diphtheria toxin, and insusceptible to the cytopathogenic effect of ECHO viruses in contrast to the one used by Arcketti (1957). Of interest is the success in producing "resistant culture" to poliovirus by Vogt et al. (1958) by means of repeated inoculations of Type 3 poliovirus into the culture of the S3 clone of HeLa cells (Puck and Marcus, 1959).

In the course of our study on the adaptation of ECHO viruses to HeLa cells, several cell lines possessing varying degrees of resistance to the cytopathogenic effect of virus have been obtained from HeLa cells surviving an exposure to a massive amount of virus. They are similar, in many respects, to the above-cited "resistant culture" of Vogt et al. (1958), but exhibit no morphological changes as compared with the parent cells. The purpose of this paper is to describe some characteristics of these resistant cultures.

中野 稔 (国立予防衛生研究所リケツチヤウイルス部) 


\section{Materials ANd Methods}

Viruses: In addition to 7 strains of ECHO viruses, one poliovirus, one adenovirus and 4 Coxsackie virus strains were used, which had the following history. The prototype ECHO viruses, Type 1 (Farouk, $\mathrm{T}_{10} \mathrm{~K}_{8}$ ), Type 2 (Cornelis, $\mathrm{T}_{9} \mathrm{~K}_{7}$ ), Type 3 (Morrisey, $\mathrm{T}_{5} \mathrm{~K}_{10}$ ), Type 5 (Noyce, $\mathrm{K}_{6}$ ), Type 6 (D'Amori, $\mathrm{K}_{9}$ ), Type 7 (Garnett, $\mathrm{K}_{9}$ ) and Type 9 (Quigley, $\mathrm{K}_{7}$ ) were sent by Dr. J. L. Melnick. These strains had undergone one monkey kidney passage and were adapted to HeLa cells in our laboratory. The Coxsackie virus chosen for the present experiments was Types 13 and 18 of Group A and Types 3 and 5 of Group B. These strains were furnished by Dr. G. Dalldorf as a form of glycerinated brains and legs of suckling mice. Lyophilized adenovirus Type 4 (GI-67) was supplied through the courtesy of Dr. I. Tateno. Mahoney strain of Type 1 poliovirus purified by Dr. N. Takemori (1958) was used. All virus seeds were prepared in HeLa cell monolayers. Aliquots stored at $-20^{\circ} \mathrm{C}$ in rubberstoppered glass tubes were the stock for seeding the cultures.

Antiserum: Prototype antisera for ECHO viruses were kindly supplied by Dr. J. L. Melnick.

Tissue culture: The HeLa cell line originally obtained from Dr. J. T. Syverton was used. The stock cultures were grown on the glass surface of $200 \mathrm{cc}$ square bottles. In transfer, cells were dispersed in $10 \mathrm{cc}$ of phosphate buffered saline (PBS) containing $0.02 \%$ disodium EDTA and no $\mathrm{Ca}^{++}$or $\mathrm{Mg}^{++}$, and $10 \mathrm{cc}$ amounts of the cell suspension made in growth medium were seeded into bottles. Tube cultures were prepared by inoculating approximately 50,000 cells suspended in $1.0 \mathrm{cc}$ of growth medium. Plasma clotted culture of human embryo skin-muscle and Cynomolgus monkey kidney tissue culture (Youngner, 1954) in stationary tubes were also prepared.

Growth media: HeLa cells were grown in medium consisting of Earle's BSS (Glucose $0.45 \%$ ), $0.5 \%$ lactalbumin hydrolysate and $0.1 \%$ yeast extract supplemented with $20 \%$ adult bovine serum (Takemori et al., 1958). The growth medium for monkey kidney cells consisted of Earle's BSS (Glucose $0.1 \%$ ) and $0.5 \%$ lactalbumin hydrolysate supplemented with $2 \%$ calf serum. Human embryo cells were maintained in the same basic medium as used for monkey cells but $20 \%$ adult bovine serum supplemented it instead of $2 \%$ calf serum. Penicillin, streptomycin and mycostatin were added routinely to all the cultures.

Maintenance media: For the purposes of virus propagation and of maintenance of cultures, a reduced amount of equine serum $(2 \%)$ was incorporated to the basic medium suited for respective cells.

Virus inoculation: Before inoculation, tube cultures were washed with $2 \mathrm{cc}$ of a mixture of Hanks' solution and PBS prepared according to Dulbecco (1954). After being rinsed, fresh maintenance medium was added into each tube being followed by virus inoculation. The amounts of virus added were as follows ; $0.1 \mathrm{cc}$ virus to $1.0 \mathrm{cc}$ medium per tube for HeLa cells, $0.2 \mathrm{cc}$ virus to $1.0 \mathrm{cc}$ medium for monkey kidney cells, and $0.15 \mathrm{cc}$ virus to $1.5 \mathrm{cc}$ medium for human embryo cells. The inoculated cultures were examind daily or with intervals of a few days with occasional changes of maintenance medium at appropriate intervals. The dilution of virus inoculated as well as the observation period is specified for each experiment in the text. Titration of virus was performed by inoculating groups of 2 tubes with serial decimal dilutions of a test fluid prepared in PBS and calculating TCID $_{50}$ according to the formula of Reed and Muench (1938). Quantities of virus were expressed by $\log _{10}$ of TCID 50 contained per cc.

Cell staining: Monolayers of HeLa cells grown on glass cover-slips in stationary tubes were inoculated with virus under conditions identical to experimental tubes and stained by Jacobson's method of Giemsa staining (1952).

\section{EXPERIMENTAL RESUltS}

\section{Cytopathogenic Effect on HeLa Cells of HeLa-Adapted Type 2 ECHO Virus and Isolation of Variant Cells Resistant to This Effect}

Cytological responses of HeLa cells to the inoculation of a massive amount of ECHO virus were examined with Types 1,2, 3, 5, 6 and 9. Four of them, Types 
1, 3, 6 and 9, exhibited such intensive CP (cytopathogenic effect) that cells sloughed off glass wall 2 to 3 days after the infection. With Types 2 and 5 , on the other hand, the CP was less intensive and not all the cells present in tubes detached from galss wall. (Plate-Figs. 5 and 9).

Fig. 1 indicates two experiments in which Type 2 ECHO virus from the 5 th HeLa passage, showing high titers both in HeLa and in human embryo cultures, was given undilutedly to HeLa tubes in $0.1 \mathrm{cc}$ amounts. In both experiments, a marked degree of cellular degeneration proceeded during the first several days and the majority of cells eventually sloughed off. Nevertheless, a small portion of the cells was left adhering to the tube wall, showing either enlargement with rounding or shrinkage with destruction. On continuation of cultivation of these cells renewing maintenance medium after every few days, production of

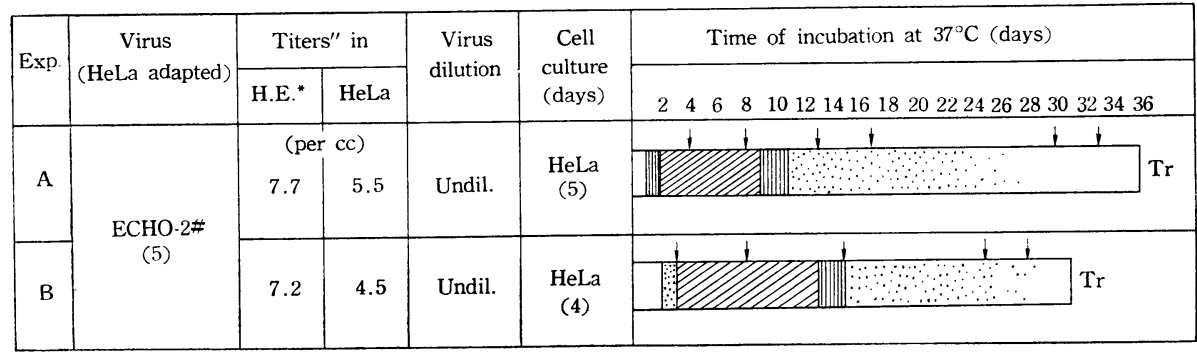

Fig. 1. Aspects of cell destruction caused by ECHO Type 2 virus (HeLa adapted) in stationary cultures of HeLa cells and isolation of resistant cultures from the progeny of surviving cells. Arrows indicate time of medium change.

\# Virus culture fluid at 5 th passage in HeLa.

" $\log _{10}$ of $\mathrm{TCID}_{50}$ per cc in the medium. Observation periods, 12 and 7 days, respectively, for HeLa and H.E.

* Culture of human embryonic skin-muscle tissue.

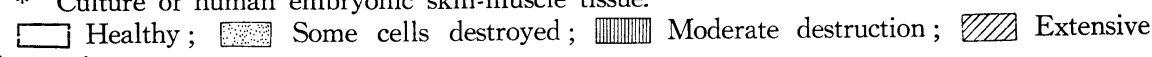
destruction.

Tr. Passage to new tubes.

new cells undistinguishable from the original healthy cells was observed after a lapse of one month, and a monolayer was formed by the new cells. The two cell lines thus obtained, named A-line and B-line according to the code of experiment illustrated in Fig. 2, could easily be maintained by culturing with the growth medium of routine use.

Each of these cell lines was subcultured and at the 4th day tested for the susceptibility to virus by inoculating the HeLa-adapted Type 2 ECHO virus to this culture after washing the cells. No CP could be recognized after 10 days' observation. The fluid removed from the culture just prior to the above virus inoculation step was also proved to contain no virus, because it induced no $\mathrm{CP}$ on new HeLa cells.

Another resistant subline was obtained from the A-line as follows. The cells of the A-line were passaged employing growth medium and reinfected with the same virus. Thus, the cycle of cell passage and virus infection was repeated 5 


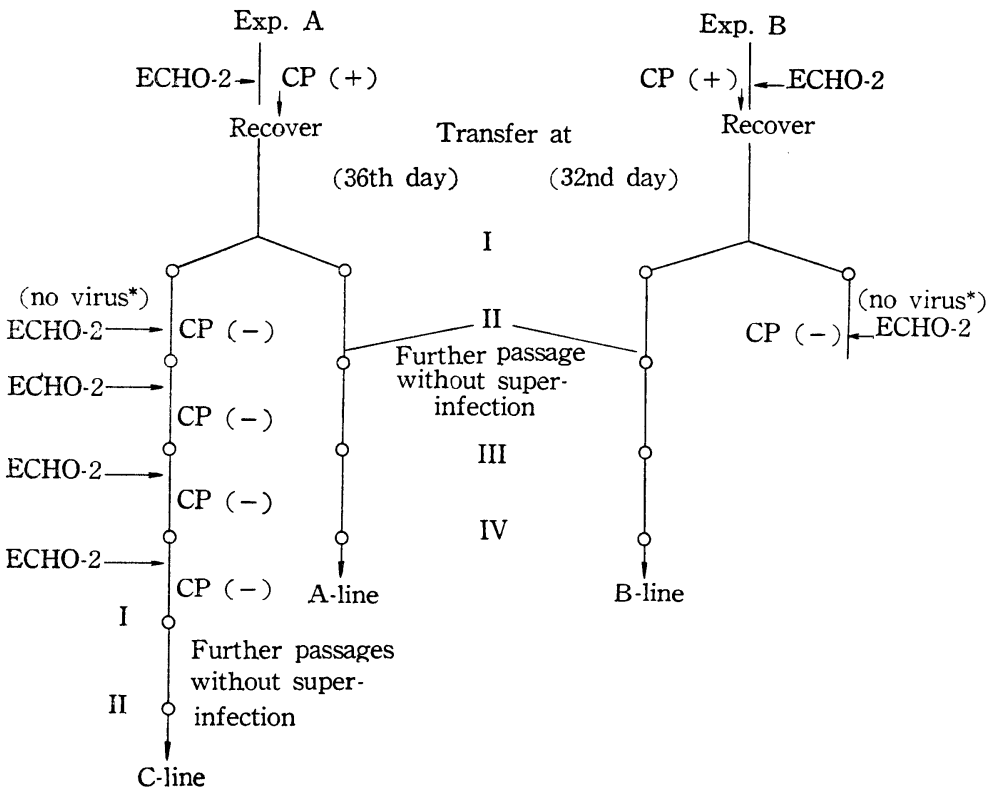

Fig. 2. History of resistant cell cultures.

None of these lines including parent $\mathrm{HeLa}$ strain were subjected to selection from clones derived from single cells.

* Tested for possible presence of active virus in culture fluids by inoculating into HeLa cell cultures.

times, and finally the cells were transferred to the ordinary type of bottle culture. This cell line was called C-line.

\section{Examination for the Resistance of the Type-2-ECHO-Resistant HeLa Cells against Heterologous ECHO Viruses}

The A-line and B-line of HeLa cells were tested for their resistance to other prototypes of ECHO virus.

a) A-line HeLa cells: The 5th subculture of the A-line and, as a control, the original $\mathrm{HeLa}$ cells were transferred respectively to a new culture under identical conditions, and 3 days later inoculated in $0.1 \mathrm{cc}$ amounts with an undiluted fluid from the 7th HeLa passage of each strain of virus tested. For each virus, the test was carried out in duplicate.

As set out in Table 1, with the homologous virus, no CP could be perceived in the resistant cell line. With Type 5, 6 and 9 too, retardation in the appearance of $\mathrm{CP}$ in the A-line cells as compared with that in the control HeLa cells was evident, and the extent of $\mathrm{CP}$ was especially low in the cases of Types 5 and 9. Likewise, a definite, though less marked, difference in the appearance time and degree of $\mathrm{CP}$ was observed between the A-line and control HeLa cells with Type 1 and 3 ECHO viruses.

b) B-line HeLa cells: A test similar to the preceding one was conducted using the B-line. The 6 th subculture of the B-line at the 2 nd culture day was 
Table 1. Comparison of susceptibility to ECHO viruses (HeLa adapted) between the A-line and parent line of $\mathrm{HeLa}$ cells

\begin{tabular}{|c|c|c|c|c|c|c|c|c|c|}
\hline \multirow{2}{*}{$\begin{array}{c}\text { Virus } \\
\text { (HeLa } \\
\text { passage) }\end{array}$} & \multirow{2}{*}{$\begin{array}{l}\text { Inoculum } \\
(0.1 \mathrm{cc} \\
\text { per tube })\end{array}$} & \multirow{2}{*}{$\begin{array}{l}\text { Cell culture } \\
\text { (3 day-old })\end{array}$} & \multicolumn{6}{|c|}{$\mathrm{CP}$ at days after inoculation of virus } & \multirow{2}{*}{$\begin{array}{l}\text { Virus titer" } \\
\text { in parent } \\
\text { HeLa (per cc) }\end{array}$} \\
\hline & & & 1 & 2 & 3 & 4 & 5 & 6 & \\
\hline ECHO-1 (7) & Undiluted & $\begin{array}{l}\text { A-line-6* } \\
\text { Parent }\end{array}$ & $\stackrel{+}{H}$ & $\stackrel{+}{+}$ & $\stackrel{+}{\mathrm{F}}$ & $H$ & + & + & 7.5 \\
\hline ECHO-2 (7) & Undiluted & $\begin{array}{l}\text { A-line- } 6 \\
\text { Parent }\end{array}$ & $\overline{+}$ & $\bar{t}$ & $\bar{H}$ & $\bar{H}$ & $\bar{H}$ & $\bar{H}$ & 5.5 \\
\hline $\mathrm{ECHO}-3(7)$ & Undiluted & $\begin{array}{l}\text { A-line-6 } \\
\text { Parent }\end{array}$ & $\bar{H}$ & $\stackrel{ \pm}{H}$ & $\stackrel{+}{H}$ & $\stackrel{+}{H}$ & $\stackrel{+}{t+H}$ & $\stackrel{+}{H}$ & 7.0 \\
\hline ECHO-5 (7) & Undiluted & $\begin{array}{l}\text { A-line-6 } \\
\text { Parent }\end{array}$ & $\bar{H}$ & $\overline{H H}$ & $\overline{\mathrm{H}}$ & $\frac{ \pm}{H}$ & \pm & $\stackrel{?}{+H}$ & 7.5 \\
\hline ECHO-6 (7) & Undiluted & $\begin{array}{l}\text { A-line- } 6 \\
\text { Parent }\end{array}$ & $\bar{H}$ & $\bar{m}$ & $\frac{ \pm}{\mathrm{H}}$ & $\stackrel{+}{H}$ & $\stackrel{+}{H}$ & $\frac{ \pm}{H+H}$ & 6.0 \\
\hline ECHO-9 (7) & Undiluted & $\begin{array}{l}\text { A-line- } 6 \\
\text { Parent }\end{array}$ & $\bar{H}$ & $\bar{H}$ & $\overline{\mathrm{H}}$ & $\bar{H}$ & $\frac{ \pm}{H}$ & $\stackrel{ \pm}{H+H}$ & 6.5 \\
\hline Cell co & ntrol & $\begin{array}{l}\text { A-line- } 6 \\
\text { Parent }\end{array}$ & $\overline{-}$ & $=$ & $\underline{-}$ & $\overline{-}$ & $\overline{-}$ & $\overline{-}$ & \\
\hline
\end{tabular}

\# Virus culture fluid at 7th passage in HeLa.

* 6th passage of resistant culture after isolation.

Virus was incculated into two tubes of each cell culture.

CP : - Same as control uninoculated cells.

? Slight damage, specificity doubtful.

\pm Small but definite areas of damage.

+ Large areas of definite damage with large remaining areas of normal cells.

H Extensive destruction.

HI Complete destruction.

$\mathrm{F}=$ Detachment from wall.

"Reciprocal of $\log _{10} \mathrm{TCID}_{50} / \mathrm{cc}$; observation period, 10 days.

$\otimes$ Detection of active virus from uninoculated tubes was tried in vain by inoculation into monkey kidney cell cultures.

given different types of ECHO virus each from the 6th HeLa cell passage. With the homologous Type 2 ECHO virus, the B-line cells demonstrated only a slight degree of cellular degeneration later than the 4 th day. Resistance to the CP by other prototypes was also seen, as was the case with the A-line cells. That is to say, with Types 5,6 and 9, retardation in the appearance as well as reduction in intensity of CP could be appreciated in the B-line cells as compared with the control cells. With Types 1 and 3 , too, some differences were discerned between the test and control cells.

This experiment was repeated using the 9th subculture of the B-line, yielding the same result, and the cover-slips carrying HeLa cells in tubes were subjected to Giemsa staining to demonstrate the extents of CP (Plate-Figs. 1-14).

In the above two experiments, check for the presence of active virus in the resistant line cells was done. Namely, two resistant cell tubes similarly incubated without the addition of virus were harvested at the $3 \mathrm{rd}$ experimental day and received 5 cycles of freeze-thawing using a $-20^{\circ} \mathrm{C}$ freezer. After the tubes were left standing for a while, the pooled supernatant was inoculated in $0.2 \mathrm{cc}$ 
amounts into monkey kidney cell cultures. No virus could be detected by this test.

\section{Examination for the Resistance of the Type-2-ECHO-Resistant HeLa against Polio, Adeno and Coxsackie Viruses}

Experiments stated in the preceding chapter indicated the acquisition by the Type-2-ECHO-resistant HeLa cell lines of the resistance against heterologous ECHO strains. Then arose a question of whether the acquired resistance was limited to ECHO viruses or covered other viruses as well. Therefore, polio, adeno and Coxsackie viruses were selected to test this point.

Table 2. Comparison of susceptibility to ECHO viruses (HeLa-adapted) between the B-line and parent line of HeLa cells

\begin{tabular}{|c|c|c|c|c|c|c|c|c|}
\hline \multirow{2}{*}{$\begin{array}{c}\text { Virus } \\
\text { (HeLa passage) }\end{array}$} & \multirow{2}{*}{$\begin{array}{c}\text { Incculum } \\
(0.1 \text { cc per tube })\end{array}$} & \multirow{2}{*}{$\begin{array}{l}\text { Cell culture } \\
(2 \text { day-old })\end{array}$} & \multicolumn{6}{|c|}{$\mathrm{CP}$ at days after inoculation of virus } \\
\hline & & & 1 & 2 & 3 & 4 & 5 & 6 \\
\hline ECHO-1 $(6)^{\#}$ & Undiluted & $\begin{array}{l}\text { B-line- } 6^{*} \\
\text { Parent }\end{array}$ & $\frac{ \pm}{H+H}$ & $\frac{ \pm}{\mathrm{F}}$ & + & $H$ & Ht & $+^{+}$ \\
\hline ECHO-2 (6) & Undiluted & $\begin{array}{l}\text { B-line- } 6 \\
\text { Parent }\end{array}$ & $\overline{+}$ & $\bar{H}$ & $\bar{H}$ & $\stackrel{?}{\mathrm{~F}}$ & $?$ & $?$ \\
\hline ECHO-3 (6) & Undiluted & $\begin{array}{l}\text { B-line-6 } \\
\text { Parent }\end{array}$ & $\frac{ \pm}{H}$ & $\frac{ \pm}{\mathrm{HH}}$ & $\stackrel{+}{\mathrm{F}}$ & + & $H$ & $\mathrm{H}^{+}$ \\
\hline $\mathrm{ECOH}-5$ (6) & Undiluted & $\begin{array}{l}\text { B-line- } 6 \\
\text { Parent }\end{array}$ & $\overline{t+}$ & $\overline{\mathrm{HH}}$ & \pm & $\stackrel{+}{\mathrm{F}}$ & + & $\pm^{+}$ \\
\hline ECHO-6 (6) & Undiluted & $\begin{array}{l}\text { B-line- } 6 \\
\text { Parent }\end{array}$ & $\bar{H}$ & $\overline{H t}$ & $\frac{ \pm}{\mathrm{F}}$ & + & $H$ & $\mathrm{Ht}^{+}$ \\
\hline ECHO-9 (6) & Undiluted & $\begin{array}{l}\text { B-line-6 } \\
\text { Parent }\end{array}$ & $\bar{H}$ & $\bar{H}$ & $\frac{ \pm}{\mathrm{F}}$ & \pm & \pm & $+^{+}$ \\
\hline \multicolumn{2}{|c|}{ Cell control } & $\begin{array}{l}\text { B-line- } 6 \\
\text { Parent }\end{array}$ & $\overline{-}$ & $\overline{-}$ & $\begin{array}{l}-\otimes \\
-\end{array}$ & $\overline{-}$ & - & $\overline{-}$ \\
\hline
\end{tabular}

For codes, see Table 1.

\# Virus culture fluid at 6th passage in HeLa.

* 6th passage of resistant culture after isolation.

+ Another resistant culture was obtained easily from surviving cells in these tubes (see Table 4).

a) Poliovirus: Mahoney strain of Type 1 poliovirus was diluted with decimal increments and inoculated to the 9 th subculture of the B-line HeLa cells at the culture age of 3 days. As a control, the parental HeLa cells of the same culture age were similarly inoculated. The appearance of $\mathrm{CP}$ and virus titers reached in 10 days were similar between both types of cells, and no marked difference in the appearance of $\mathrm{CP}$ could be appreciated between them (PlateFigs. 15 and 16). Table 3 presents, for the sake of brevity, only the CP induced by the $10^{-3}$ dilution of the seed virus.

In the next experiment, illustrated in Exp. 2 of Table 3, the same virus was given undilutedly to 3 days cultures of the A-line and parental HeLa cells. Again, no difference could be seen in the $\mathrm{CP}$ between the two types of HeLa cells. 
b) Adenovirus: Type 4 adenovirus in a form of fluid medium from $\mathrm{HeLa}$ culture was diluted $1: 5$, and inoculated to the 7th subculture of the A-line, 9th subculture of the B-line and control parental HeLa cells, all at the culture age of 3 days. In all the 3 types of cells, CP appeared markedly in 2 days showing no appreciable difference among them (Plate-Figs. 17 and 18).

c) Coxsackie virus: Experiments of a design similar to the preceding ones were carried out employing 4 Coxsackie virus strains and the C-line cells. The titration results of Type 18 of Group A and Type 5 of Group B viruses based on the CP appearing in the C-line and parental HeLa cells 7 days following inoculation differed little, whereas the other two viruses, Type 13 of Group A

Table 3. Comparison of susceptibility to polio, adeno and Coxsackie viruses between the parent and resistant (A, B and C) lines of HeLa cells

\begin{tabular}{|c|c|c|c|c|c|c|c|c|c|}
\hline \multirow{3}{*}{ Exp. } & \multirow{3}{*}{ Virus } & \multicolumn{2}{|c|}{ Comparative titration } & \multicolumn{6}{|c|}{$\mathrm{CP}$ at days after incculation of } \\
\hline & & \multirow{2}{*}{$\begin{array}{l}\text { Cell cul. } \\
\text { (3 day-old) }\end{array}$} & \multirow{2}{*}{$\begin{array}{l}\text { Virns titer" } \\
\left(\text { TCID }_{50} / \mathrm{cc}\right)\end{array}$} & \multirow{2}{*}{$\begin{array}{l}\text { Virus } \\
\text { dil. }\end{array}$} & \multicolumn{5}{|c|}{ Days } \\
\hline & & & & & 1 & 2 & 3 & 4 & 5 \\
\hline 1 & $\begin{array}{l}\text { Polio-MAH. } \\
\text { (pl-459) }\end{array}$ & $\begin{array}{l}\text { B-line-9 } \\
\text { Parent }\end{array}$ & $\begin{array}{l}7.0 \\
7.5\end{array}$ & $\begin{array}{l}10^{-3} \\
10^{-3}\end{array}$ & $\overline{-}$ & + & $H$ & $\begin{array}{l}H \\
H\end{array}$ & \\
\hline \multirow[b]{2}{*}{2} & $\begin{array}{l}\text { Polio-MAH. } \\
\text { (pl-459) }\end{array}$ & $\begin{array}{l}\text { A-line-7 } \\
\text { Parent }\end{array}$ & $\overline{7.5}$ & $\begin{array}{l}10^{-0} \\
\prime \prime\end{array}$ & + & HH & $\begin{array}{l}\mathrm{F} \\
\mathrm{F}\end{array}$ & & \\
\hline & Adeno-4 & $\begin{array}{l}\text { A-line-7 } \\
\text { B-line-9 } \\
\text { Parent }\end{array}$ & $\frac{-}{-}$ & $\begin{array}{l}10^{-0.7} \\
\prime \prime \\
\prime \prime\end{array}$ & $=$ & $\begin{array}{l}+ \\
+ \\
+\end{array}$ & $\begin{array}{l}+ \\
+ \\
+\end{array}$ & $\begin{array}{l}H \\
H \\
H\end{array}$ & $\begin{array}{l}H \\
H \\
H\end{array}$ \\
\hline \multirow{4}{*}{3} & $\begin{array}{l}\text { Coxsackie, A-13 } \\
\text { (HL-1) }\end{array}$ & $\begin{array}{l}\text { C-line- } 41 \\
\text { Parent }\end{array}$ & $\begin{array}{l}5.0 \\
6.5\end{array}$ & $\begin{array}{l}10^{-3} \\
\prime \prime\end{array}$ & - & $\begin{array}{l} \pm \\
\pm\end{array}$ & $\begin{array}{l}H \\
H\end{array}$ & $\begin{array}{l}H \\
H\end{array}$ & $H$ \\
\hline & $\begin{array}{c}\text { Coxsackie, A-18 } \\
(\text { HL-1) }\end{array}$ & $\begin{array}{l}\text { C-line- } 41 \\
\text { Parent }\end{array}$ & $\begin{array}{l}7.0 \\
7.0\end{array}$ & $\begin{array}{l}10^{-3} \\
\prime \prime\end{array}$ & - & + & $\begin{array}{l}H \\
H\end{array}$ & $H$ & $H$ \\
\hline & $\begin{array}{l}\text { Coxseckie, B-3 } \\
(\text { HL-1) }\end{array}$ & $\begin{array}{l}\text { C-line- } 41 \\
\text { Parent }\end{array}$ & $\begin{array}{l}6.5 \\
7.5\end{array}$ & $\begin{array}{l}10^{-3} \\
\prime \prime\end{array}$ & $\overline{-}$ & $\begin{array}{l}+ \\
+\end{array}$ & $H$ & $\begin{array}{l}H \\
H\end{array}$ & $\mathrm{HH}$ \\
\hline & $\begin{array}{c}\text { Coxsackie, B-5 } \\
(\text { HL-1) }\end{array}$ & $\begin{array}{l}\text { C-line- } 41 \\
\text { Parent }\end{array}$ & $\begin{array}{l}7.5 \\
7.5\end{array}$ & $\begin{array}{l}10^{-3} \\
11\end{array}$ & $\overline{-}$ & $\begin{array}{l}+ \\
+\end{array}$ & $\underset{H}{H}$ & $H$ & $\mathrm{HH}$ \\
\hline
\end{tabular}

For codes, see Table 1.

"Reciprocal of $\log _{10} \mathrm{TCID}_{50} / \mathrm{cc}$ using two tubes per dilution.

Observed for 10 days.

and Type 3 of Group B, showed lower titers in the C-line than in the parental HeLa cells. The degree of CP in the final stage also showed little difference between the test and control cells, though retardation in its appearance was noticed, in all the cases, in the C-line HeLa cells.

\section{Isolation of Sublines of the Type-2-ECHO-Resistant HeLa Strain Possessing Resistances to the CP of Other Prototype ECHO Viruses}

Earlier attempts to isolate HeLa cell lines resistant to the $\mathrm{CP}$ of Type 1, 3 or 6 ECHO virus were encountered by the difficulty that these viruses, as stated 
above, induced too intensive degeneration of cells in an early stage of infection leaving few cells remaining on glass wall. However, the modified resistances to these Types gained by the Type-2-ECHO-resistant line made these attempts feasible. Namely, the B-line cell cultures used in the experiment of Table 2 were further maintained for certain periods of time in the presence of the above ECHO viruses after which HeLa cells morphologically undistinguishable from the parent cells were separated. Another subline resistant to either Type 5 or Type 9 was produced in the same manner. These cell lines have since been passaged with the ordinary growth medium for more than one year, except the Type-3-resistant line which was lost accidentally during the passage. From the viewpoint of morphology, no distinction is possible between these cell lines and the parental HeLa cells.

\section{Stability of the Resistance to CP of the Resistant Cell Lines over a Prolonged Period of Cultivation}

The Type-2-ECHO-resistant line and its sublines possessing resistances to other prototypes received repeated passages for a period exceeding one year without exposure to virus and then examined for the stability of their acquired resistances against the $\mathrm{CP}$ of $\mathrm{ECHO}$ viruses.

The cell lines here tested were the $\mathrm{C}$-line and 4 sublines of the Type-2resistant B-line which were resistant to Types 1, 5, 6 and 9. When tested, the C-line was at the level of the 68th passage from its separation and the Type-1, $-5,-6$ and -9 resistant lines were at the 56th, 62nd, 51st and 61st passages, respectively, from their separation out of the Type-2-resistant B-line. The passage history was denoted by the codes of C-HL(2)-68, B-HL $(2,1)-56$, B-HL $(2,5)-62$, $\mathrm{B}-\mathrm{HL}(2,6)-51$ and $\mathrm{B}-\mathrm{HL}(2,9)-61$, where figures in parentheses indicate the prototypes to which the cells are resistant and those following the parentheses the passage level. As a control, the parental HeLa cells were grown under identical condition, and test was performed in a manner similar to the experiments of Tables 1 and 2. The results obtained are summarized in Table 4 .

In the parental HeLa cells, CP was evident after 24 hours with all the viruses tested, especially with Types 1, 3, 6 and 9 which resulted in sloughing-off of almost all cells at the 48th hour showing high virus titers in the fluid. With Types 2, 5 and 7 , the velocity with which cellular degeneration proceeded was less rapid and the virus titers of the fluid were slightly lower than was observed with the above 4 viruses.

The C-line HeLa cells, on the contrary, demonstrated a high resistance to the homologous Type 2 ECHO virus, eliciting only a slight degree of cellular degeneration later than the 4th day following the infection and complete recovery therefrom soon afterwards. The resistance gained by this cell line covered not only the homologous but also the heterologous ECHO viruses. The resistances to Types 5,7 and 9 were expressed by retardation in appearance and reduction in intensity of $\mathrm{CP}$ as compared with the parental HeLa cells. Viruses capable of inducing high degrees of $\mathrm{CP}$ in the parental $\mathrm{HeLa}$ cells such as Types 1, 3 and 6 also revealed some extent of lowering of $\mathrm{CP}$ in the $\mathrm{C}$-line cells.

Results obtained with the Type-5-resistant HeLa cells, B-HL(2,5), were similar 
to those of the C-line cells. However, the resistance against the homologous Type 5 ECHO virus was not as conspicuous as shown by the C-line cells against its homologous Type 2 virus.

The Type-9-resistant line, B-HL(2,9), disclosed a general trend of increased resistance to all the prototypes tested as compared with the above two resistant cell lines. Especially marked were its resistances to Types 5 and 7 as well as to the homologous Type 2. A strange fact was that the resistance against the homologous Type 9 virus appeared to be lower than that against the heterologous Types 5 and 7 . On the other hand, even with Types 1,3 and 6 , whose $\mathrm{CP}$ in the parental HeLa cells always surpassed that of other prototype viruses, marked degrees of suppression of $\mathrm{CP}$ could be seen.

Table 4. Comparison of susceptibility to ECHO viruses (HeLa-adapted) among the parent line, C-line and other resistant cultures derived from the B-line HeLa cells receiving passages for a period of more than one year

\begin{tabular}{|c|c|c|c|c|c|c|c|}
\hline Virus & $\underset{(10) \#}{\mathrm{ECHO}}$ & $\underset{(10)}{\mathrm{ECHO}-5}$ & $\underset{(5)}{\mathrm{ECHO}-7}$ & $\underset{(10)}{\mathrm{ECHO}-9}$ & $\underset{(7)}{\mathrm{ECHO}-3}$ & $\underset{(10)}{\text { ECHO- } 6}$ & $\underset{(10)}{\text { ECHO-1 }}$ \\
\hline $\begin{array}{l}\text { Virus titer in } \\
\mathrm{HeLa} \text { (TCID50/cc) }\end{array}$ & $6.0^{\prime \prime}$ & 6.0 & 6.5 & 7.5 & 7.0 & 7.5 & 7.5 \\
\hline $\mathrm{CP}$ & \multicolumn{7}{|c|}{$\mathrm{CP}$ at days after inoculation of virus } \\
\hline $\begin{array}{l}\text { Cell } \\
\text { cul. (4 day-old) }\end{array}$ & 12345 & 2345 & 123345 & 12345 & 12345 & 12345 & 12345 \\
\hline Parent $\mathrm{HeLa}$ & H H W \# H & H H W H H & $+\mathrm{H}+\mathrm{H}+\mathrm{H}$ & HF & $\mathrm{HF}$ & \#F & HI F \\
\hline C-HL (2)-68* & --- \pm \pm & $?-+\#+\#$ & $? \pm+\#+\#$ & $\pm+\mathrm{WH}$ & $\pm \# F$ & $+\# F$ & 上 $\mathrm{HF}$ \\
\hline B-HL $(2,5) \cdot 62=$ & --- \pm \pm & $?- \pm \#+\#$ & $? ? \pm+\#$ & $\pm+\# F$ & $\pm+\# \mathrm{~F}$ & $+\# \mathrm{~F}$ & $\pm \#$ \# F \\
\hline B-HL $(2,9)-61$ & ----- & ----- & --- \pm+ & $-? \pm++$ & $? \pm \pm \pm+$ & $+++H+H$ & $\pm \pm \pm+\#$ \\
\hline B-HL $(2,6)-51$ & ----- & ----- & ---- & ----- & ----- & ---- & ----- \\
\hline B-HL $(2,1)-56$ & ----- & ----- & $---\cdots$ & ----- & ----- & ----- & ----- \\
\hline
\end{tabular}

For codes, see Table 1. Uninoculated culture of each line served as control.

\# Virus culture fluid at 10th passage in HeLa.

* 68th passage of C line-HeLa after isolation.

$=$ Resistant culture derived from the B-line of HeLa cells after incculation of ECHO Type 5 virus (see Table 2).

"Reciprocal of $\log _{10}$ TCID $50 / c c$ in parent HeLa. Observed for 10 days.

Finally, the Type-1 and Type-6 resistant lines, B-HL(2,1) and B-HL(2,6), were proved to be of higher resistances than B-HL $(2,9)$ as against all the viruses. Virtually, a complete inhibition of CP occurred not only with the homologous virus but also with all the other ECHO viruses tested including prototypes capable of causing intensive $\mathrm{CP}$ such as Types 1,3 and 6 .

It was established, thus, that the more intensive $\mathrm{CP}$ was induced primarily by a virus used for the production of resistant cells, the stronger overall resistances against all prototypes were conferred to the resulting resistant cell line. At the same time, so long as a virus of weaker $\mathrm{CP}$ was used, even repeated superinfections of cells with it could not bring the acquired resistances of the progeny cells beyond a certain limit, as exemplified by C-HL(2)-68 in the above experiment. It was also warranted that the resistances of cells once acquired were stable over a prolonged period of cultivation, despite the fact that these cell lines had not been subjected to any clone selection. 
Table 5. Virogenicity test of resistant cultures at various passage levels

\begin{tabular}{|c|c|c|c|c|c|c|c|c|c|c|c|}
\hline \multirow{4}{*}{ Cell line } & \multicolumn{11}{|c|}{ Detection of virus from resistant cells using monkey kidney culture* } \\
\hline & \multicolumn{2}{|c|}{ Exp. 1} & \multicolumn{2}{|c|}{ Exp. 2} & \multicolumn{2}{|c|}{ Exp. 3} & \multicolumn{2}{|c|}{ Exp. 4} & \multicolumn{3}{|c|}{ Exp. 5} \\
\hline & \multirow{2}{*}{\multicolumn{2}{|c|}{$\begin{array}{c}\text { Cell Virus } \\
\text { passage }\end{array}$}} & \multirow{2}{*}{\multicolumn{2}{|c|}{$\begin{array}{c}\text { Cell } \\
\text { passage Virus }\end{array}$}} & \multirow{2}{*}{\multicolumn{2}{|c|}{$\begin{array}{c}\text { Cell } \\
\text { passage Virus }\end{array}$}} & \multirow{2}{*}{\multicolumn{2}{|c|}{$\begin{array}{c}\text { Cell } \\
\text { passage }\end{array}$}} & \multirow{2}{*}{$\begin{array}{c}\text { Cell } \\
\text { passage }\end{array}$} & \multicolumn{2}{|l|}{ Virus } \\
\hline & & & & & & & & & & 1st $2 \mathrm{n}$ & nd \\
\hline $\begin{array}{c}\text { C-HL } \\
(2)\end{array}$ & 13 & - & 14 & - & 17 & 一 & 32 & - & 71 & - & - \\
\hline $\begin{array}{l}\text { B-HL } \\
(2,1)\end{array}$ & & & 15 & - & & & 31 & - & 63 & - & - \\
\hline $\begin{array}{l}\text { B-HL } \\
(2,5)\end{array}$ & 16 & - & 17 & - & 20 & - & 34 & - & 66 & - & - \\
\hline $\begin{array}{l}\text { B-HL } \\
(2,6)\end{array}$ & 15 & + & 16 & + & & & 31 & - & 57 & - & - \\
\hline $\begin{array}{l}\text { B-HL } \\
(2,9)\end{array}$ & 14 & - & 15 & 一 & 18 & - & 32 & - & 66 & - & - \\
\hline $\begin{array}{c}\text { Material } \\
\text { tested }\end{array}$ & $\begin{array}{l}\text { Fluid poc } \\
\text { frcm } 2 \\
\text { (10-day }\end{array}$ & $\begin{array}{l}\text { oled } \\
\text { tubes } \\
\text { cul.) }\end{array}$ & $\begin{array}{l}\text { Fluid po } \\
\text { from } 2 \\
\text { (2-day }\end{array}$ & $\begin{array}{l}\text { oled } \\
\text { tubes } \\
\text { cul.) }\end{array}$ & $\begin{array}{l}\text { Fluid poc } \\
\text { from } 2 \\
\text { (7-day }\end{array}$ & $\begin{array}{l}\text { oled } \\
\text { tubes } \\
\text { cul.) }\end{array}$ & $\begin{array}{c}\text { Fluid \& } \\
\text { from } 2 \\
\text { (8-day } \\
\text { Freeze-th } \\
3 \text { times. }\end{array}$ & $\begin{array}{l}\text { cells } \\
\text { tubes } \\
\text { cul.) } \\
\text { hawing, } \\
\text {. }\end{array}$ & $\begin{array}{l}\text { 1st sample } \\
\text { Fluid fro } \\
\text { bottle (9- } \\
\text { 2nd sampl } \\
\text { Fluid \& } \\
\text { from the } \\
\text { bottle (13 } \\
\text { cul.) Free } \\
\text { thawing, }\end{array}$ & $\begin{array}{l}\text { e: } \\
\text { om one } \\
\text { day cul. } \\
\text { le : } \\
\text { cells } \\
\text { same } \\
\text { 3-day } \\
\text { eze- } \\
5 \text { time }\end{array}$ & \\
\hline $\begin{array}{l}\text { Note : } \\
\text { Fluid } \\
\text { change } \\
\text { after } \\
\text { seeded }\end{array}$ & $\begin{array}{l}\text { Replaced } \\
\text { M. S. } \\
\text { 4th and } \\
\text { days }\end{array}$ & $\begin{array}{l}\text { with } \\
6 \text { th }\end{array}$ & No replac & cement & $\begin{array}{c}\text { Replaced } \\
\text { M. S. } \\
\text { 4th and } \\
\text { days }\end{array}$ & $\begin{array}{l}\text { with } \\
6 \text { th }\end{array}$ & $\begin{array}{l}\text { Replaced } \\
\text { M. S. } \\
\text { 2nd, 4th } \\
\text { 6th day }\end{array}$ & $\begin{array}{l}\text { with } \\
\text { and } \\
\text { ays }\end{array}$ & $\begin{array}{l}\text { Replaced } \\
\text { M. S. 7th } \\
\text { 11th days }\end{array}$ & $\begin{array}{l}\text { with } \\
\text { h and } \\
\text { s }\end{array}$ & \\
\hline
\end{tabular}

* $0.2 \mathrm{cc}$ sample was inoculated into each of two tubes of monkey kidney culture and observed for 14 days.

M. S. : Maintenance medium.

\# Not less than $5 \times 10^{6}$ cells per bottle.

\section{Examination for the Production of Active Virus by the Resistant Cell Lines}

Cieciura et al. (1957) reported that HeLa cells acquiring resistance to Newcastle disease virus (NDV) after being exposed to it revealed, after 2 years cultivation, the presence of virus therein by its reactivation on transfer of the cells onto a feeder-layer, X-irradiated HeLa cells. Vogt et al. (1958) also pointed out that, in the course of development of polio-resistant HeLa cells, earlier cultures sometimes produced active virus. In the present study, it was noted earlier (Fig. 2, Tables 1 and 2) that no active virus production could be seen even in the very initial culture of the resistant cell lines, A, B and C. Whether this holds true for other resistant cell lines subsequently obtained was then explored.

The resistant HeLa cell lines at varying passage levels were cultured for 2 to 13 days and the fluid or whole culture treated with freeze-thawing was ex- 
amined for the presence of virus. The results, recorded in Table 5, clearly indicated that none of these cell lines demonstrated active virus production, except B-HL $(2,6)$ which showed active virus at the 15 th and 16 th passages. The virus recovered turned out to be ECHO Type 6 by neutralization tests. The cell passages later than the 31st passage of $\mathrm{B}-\mathrm{HL}(2,6)$, however, involved no more active virus.

\section{Discussion}

The experiments herein stated indicate that the establishment of sublines of HeLa cells possessing resistances against the CP of ECHO viruses is possible by means of bringing the cells in a prolonged contact with a massive amount of virus. No inverse relation between the inoculum size of virus and the extent of cellular degeneration could be observed in the present attempts. However, it is noteworthy that such variant cells readily appeared with a high reproducibility when HeLa cells were exposed to Type 2 ECHO virus inoculated en masse. Morphologically, the resistant cells thus established could hardly be differentiated from the parental HeLa cells. On the other hand, cell lines resistant to ECHO prototypes other than Type 2 were difficult to obtain from the parental HeLa cells, since the CP caused in the latter cells was too severe. Use of antiserum for isolation of virus-resistant cell lines might have contributed to the establishment of the HeLa sublines resistant to the abovedescribed ECHO viruses of intensive CP. In the present experiments, this was possible only by means of the two-step process, first the development of Type2-resistant and then doubly resistant cell lines.

Any alternative method for developing resistant cell lines may be worth trying, because it might be possible by some means or other to obtain another resistant cells which differ from parental HeLa in its morphological appearance. Vogt et al. (1958) isolated elongated fusiform HeLa cells which were resistant to poliovirus. As just mentioned, the resistant cultures herein described resembled the parental HeLa cells in morphological appearance and retained the resistances to ECHO viruses during the cultivation for more than a year. This is a contrast to the emphasis laid by Stulberg et al. (1958) that differences in morphology are of significance with respect to virus susceptibility of cells. They indicated the presence of marked differences in ECHO virus susceptibility between a fibroblast-like cell strain (Detroit-196 Fb-L) and its epithelial-like derivative (Detroit-196 Fb-L).

The mechanism by which the resistant cell lines came to appearance might be explained by either of the following two alternatives. The first explanation is that resistant cells had already occupied a certain minor proportion of the parental HeLa cells and were brought forward as a result of the selection by the massive inoculation of virus. The above-stated fact that there was no morphological changes during the course of such resistant cell selection may support this possibility, and if this were true one might be able to determine the proportions of various types of resistant cells in the original HeLa cell culture by some appropriate means. However, this explanation does not seem to account for the reason why the two-step selection was needed for the development of 
Type-1, -3 and -6 resistant cell lines and why the cellular resistance established followed a gradient depending upon the virus used for selection. The second explanation is that a persistent latent viral infection, or virogenicity, was induced in randomly selected cells, resulting in acquisition by the cells of interfering capacity against the homologous or closely related viruses.

The second explanation may be given support in light of recent works indicating the presence of persistent viral infection of cultured cells which showed interference against unrelated cytopathogenic agents (Henle et al., 1958; Bergs et al., 1958). In the persistent infection of Earle's L cells with WEE virus (Chambers, 1957), the role of interference in bringing about cellular resistance against the homologous virus was suggested by the fact that the cellular resistance was present in concomitance with the presence of virus detectable in the culture. Chanock (1955) reported that the monkey kidney cells which had accidentally been infected with Newcastle disease virus and escaped from its destructive action exhibited varying degrees of resistance to polioviruses and to several types of ECHO virus. Interference between polioviruses and Coxsackie B or ECHO virus in monkey kidney culture has also been reported (Lycke, 1958).

Attribution to interference of the phenomena observed in the present study might be justified by recovery of virus from the resistant cell lines established, and various attempts have been made along this line, attention being paid thereby to the fact that manifestation of $\mathrm{CP}$ depends on subtle change in such factors as medium pH (Barrow and Karzon, 1957). Nevertheless, temporary virogenicity was seen only in the cell line derived from Type 6 ECHO virusinfected HeLa cells, which showed no release of active virus any more subsequent to the 31st passage. It is also known that antibodies can play a role in masking virus infection (Ginsberg, 1958; Ackermann, 1957), but it is far from likely in the present cases that adult horse serum at the concentrations used contained non-specific antibodies in sufficient amounts to exert any interfering effect on active virus production.

One might be reminded, in this connection, that an increase in the cellular susceptibility to virus was demonstrated by $\mathrm{X}$-irradiated giant $\mathrm{HeLa}$ cells and patas monkey kidney cells (Cieciura et al., 1957 ; Hsiung, 1959). However, use of this method for the detection of latent viral infection may not necessarily be successful, because Vogt et al. (1958) indicated that the proportion of virusyielding cells counted on monolayers of monkey kidney cells at an early passage of polio-resistant HeLa culture did not differ significantly from that determined on monolayers of giant HeLa cells. Though this technic seems to be worth trying in our further study, it thus remains an implication at this moment that a persistent latent viral infection may have existed in the resistant HeLa cell lines obtained.

Should the second possibility be valid, the present observation would add another example to what can be categorized as animal virus lysogenicity. Thus far, only one such case is known, that is Newcastle disease virus in HeLa cells (Cieciura et al., 1957 ; Puck and Cieciura, 1958). In fact, in the case of bacteriabacteriophage systems, lysogenic strains are generally immune to the homologous temperate phage and its virulent mutants, while being not immune to phages 
which are not serologically related to the homologous phage. The properties of immunity has already been defined (Bertani, 1958). In the ECHO-resistant $\mathrm{HeLa}$ cell lines, the acquired resistance covered homologous and some heterologous ECHO virus types but not other viruses tested. Furthermore, the most interesting observation was that the more intensive $\mathrm{CP}$ was induced in the parental HeLa cells by a virus, the stronger overall resistances covering all ECHO types were attained by the surviving progeny cells. Although the significance of this phenomenon is obscure at the present moment, it appears to give a clue to solve the problems under study with accumulation of more experimental data in the future.

\section{SUMMARY}

When a massive amount of HeLa-adapted Type 2 ECHO virus was inoculated to HeLa cells, a certain proportion of cells remained viable after a long period of cultivation, from which were obtained HeLa cells possessing varying degrees of resistance to the $\mathrm{CP}$ of ECHO viruses. This was reproducible, and different resistant cell lines were established. The resistance acquired was limited to ECHO viruses including heterologous prototypes but did not cover other viruses such as polio, adeno or Coxsackie viruses. Similar attempts with ECHO viruses other than Type 2 failed due to the fact that those viruses, especially Types 1 , 3 and 6 , caused too intensive CP in the original HeLa cells. However, with the use of the Type-2-ECHO-resistant HeLa cells in place of the original HeLa in these attempts, it became possible to isolate HeLa cell lines doubly resistant to Type 2 and each of the secondly inoculated virus. The resistances of cells thus established were stable during cultivation for a period of more than one year, although no purification of these cells by clone selection had been done in between the passage. Morphologically, all the resistant cell lines were undistinguishable from the parental HeLa cells. Whether the resistant cells had preexisted in the cellular population of the parent HeLa or they can be attributed to an interference phenomenon evoked by a persistent latent viral infection is discussed.

The author wishes to express his sincere gratitude to Dr. M. Kitaoka, Dr. N. Takemori and Dr. K. Yoshino for their valuable criticisms and help in preparing this paper. The author is indebted to Drs. K. Suzuki and N. Kishi for their cooperation in this investigation and the skilful technical assistance of Mrs. K. Karasawa is also gratefully acknowledged.

\section{REFERENCES}

ACKermanN, W. W. (1957): Mechanism of persistent and masked infections in tissue culture. Ann. New Vork Acad. Sc., 67, 392-402.

ARCKetTI, I., Weston, J. \& WenNER, H. A. (1957): Adaptation of ECHO viruses in HeLa cells; their use in complement fixation. Proc. Soc. Exper. Biol. \& Med., 95, 265-270.

BANG, F. B. \& GEY, G. O. (1952): Comparative susceptibility of cultured cell strains to the virus of eastern equine encephalomyelitis. Bull. Johns Hopkins Hosp., 91, 427-461.

BARRON, A. L. \& KARZON, D. T. (1957): Effect of $\mathrm{pH}$ on cytopathogenicity of orphan viruses. Proc. Soc. Exper. Biol. \& Med., 94, 393-399.

Bergs, V. V., Henle, G., Deinhardt, F. \& Henle, W. (1958): Studies on persistent infections of tissue cultures. II. Nature of the resistance to vesicular stomatitis virus. J. 
Exper. Med., 108, 561-572.

Bertani, G. (1958): Lysogeny. Adv. Virus Res., 5, 151-193.

CHAMBERS, V. C. (1957): The prolonged persistence of western equine encephalomyelitis virus in cultures of strain $\mathrm{L}$ cells. Virol., 3, 62-75.

CHANG, R. S. (1957): Isolation of nutritional variants from conjunctival and HeLa cells. Proc. Soc. Exper. Biol. \& Med., 96, 818-820.

CHANOCK, R. M. (1955): Cytopathogenic effect of Newcastle virus in monkey kidney cultures and interference with poliomyelitis viruses. Proc. Soc. Exper. Biol. \& Med., 89, 379-381.

Cieciura, S. J., Marcus, P. I. \& Puck, T. T. (1957): The use of X-irradiated HeLa cell giants to detect latent virus in mammalian cells. Virol., 3, 426-428.

DulBecco, R. \& VOGT, M. (1954): Plaque formation and isolation of pure lines with poliomyelitis viruses. J. Exper. Med., 99, 167-182.

EARLE, W. R. \& NeTtleship, A. (1943): Production of malignancy in vitro. V. Results of injections of cultures into mice. J. Nat. Cancer Inst., 4, 213-227.

GEY, G. O., COFFMAN, W. D. \& KUBICEK, M. T. (1952): Tissue culture studies of the proliferative capacity of cervical and normal epithelium. Cancer Res.,' 12, 264-265.

GINSBERG, H. S. (1958): A consideration of the role of serum inhibitors in latency and analysis of persistent adenovirus infection of mammalian cells. Symposium on Latency and Masking in Viral and Rickettsial Infections-Walker-Hanson-Evans. Burgess Pub. Co.

GOldBlATT, H. \& CAMERON, G. (1953): Induced malignancy in cells from rat myocardium subjected to intermittent anaerobiosis during long propagation in vitro. J. Exper. Med., 97, 525-552.

Grayston, T., McCarthy, M. A., Smith, M. \& Loosli, C. G. (1958): Adenoviruses. II. The sensitivity of different tissue culture strains of cells to adenoviruses. J. Infect. Dis., 103, 75-101.

HAFF, R. F. \& SwIM, H. E. (1957): Isolation of a nutritional variant from a culture of rabbit fibroblasts. Science, $125,1294$.

Henle, G., Deinhardt, F., Bergs, V. V. \& Henle, W. (1958): Studies on persistent infections of tissue cultures. I. General aspects of the system. J. Exper. Med., 108, 537-560.

HsIUNG, G. D. (1959) : Effect of X-irradiation on patas monkey kidney cell susceptibility to enteroviruses. Virol., $7,140-149$.

JACORSON, W. \& WEBB, M. (1952): The two types of nucleoproteins during mitosis. Exper. Cell Res., 3, 163-183.

LENNOX, E. S. \& Kaplan, A. S. (1957): Action of diphtheria toxin on cells cultivated in vitro. Proc. Soc. Exper. Biol. \& Med., 95, 700-702.

LYCKE, E. (1958): Interference between poliomyelitis virus and Coxsackie B or ECHO viruses. Arch. ges. Virusforsch., 8, 351-359.

Perry, V. P., Evans, V. J. \& EARle, W. R. (1955): Cultivation of large cultures of HeLa cells in horse serum. Science, 121, 805.

Puck, T. T. \& Fisher, H. W. (1956): Genetics of somatic mammalian cells. I. Demonstration of the existence of mutants with different growth requirements in a human cancer cell strain (HeLa): J. Exper. Med., 104, 427-434.

Puck, T. T. \& Marcus, P. I. (1956): Action of X-rays on mammalian cells. J. Exper. Med., 103, 653-666.

Puck, T. T. \& Cieciura, S. J. (1958): Studies on the virus carrier state in mammalian cells. Symposium on Latency and Masking in Viral and Rickettsial Infections-WalkerHanson-Evans. Burgess Pub. Co.

Quersin-THIRY, L. (1958): Action of anticellular sera on virus infections. J. Immunol., $81,253-260$.

REED, L. J. \& MUENCH, H. (1938): A simple method of estimating fifty per cent endpoints. Am. J. Hyg., 27, 493-497. 
SANFORD, K. K., Likely, G. D. \& EARLE, W. R. (1954): The development of variations in transplantability and morphology within a clone of mouse fibroblasts transformed in sarcoma-producing cells in vitro. J. Nat. Cancer Inst., 15, 215-237.

Sanford, K. K., Earle, W. R., Shelton, E., Schilling, E. L., Duckesne, E. M., Likely, G. D. \& BECKER, M. M. (1950): Production of malignancy in vitro. XII. Further transformations of mouse fibroblasts to sarcomatous cells. J. Nat. Cancer Inst.; 11, 351-375.

SCHERER, W. F. (1955): Comparative susceptibility of cells of the same type to infection by poliomyelitis virus. Ann. New York, Acad. Sc., 61, 806-821.

SHEFFIELD, F. W. \& CHURCHER, G. M. (1957): The serial propagation of poliomyelitis viruses in cells derived from rabbit embryo kidney. Brit. J. Exper. Path., 38, 155-159.

Stulberg, C. S., Page, R. H. \& Berman, L. (1958): Comparative behavior of 16 echo virus types in fibroblast-like and epithelial-like human cell strains. Proc. Soc. Exper. Biol. \& Med., 97, 355-359.

TAkemori, N., Nomura, S., Nakano, M., Morioka, Y., Henmi, M. \& Kitaoka, M. (1958) : Mutation of polioviruses to resistance to neutralizing substances in normal bovine sera. Virol., 5, 30-55.

VogT, M. \& DulBE.CCO, R. (1958): Properties of a HeLa cell culture with increased resistance to poliomyelitis virus. Virol., 5, 425-434.

YOUNGNER, J. S. (1954): Monolayer tissue cultures. I. Preparation and standardization of suspensions of trypsin-dispersed monkey kidney cells. Proc. Soc. Exper. Biol. \& Med., $85,202-205$.

\section{ADDENDUM}

After this manuscript was prepared, the author read a report of Darnell et al. which is concerning the variation of HeLa cells in plaque forming ability (DARNELL, J. E., Jr. \& SAUYER, T. K. (1959): Variation in plaque forming ability among parental and clonal strains of HeLa cells. Virol., 8, 223-229) 


\section{Explanation of Plates}

The comparative cytopathogenic effects of $\mathrm{HeLa}$ adapted $\mathrm{ECHO}$, polio and adeno viruses upon parental and resistant HeLa cells (at 9th pass of B-line HeLa, Text-Fig. 2) grown on a cover slip in a stationary tube. All photomicrographs were taken by Mr. S. Noda and Mr. T. Kasai of cultures stained with Giemsa. The magnification is 250 .

Figs. 1-2. Normal parental (Fig. 1) and resistant (Fig. 2) HeLa cell cultures 5 days after implantation.

Figs. 3-4. Cultures of parental (Fig. 3) and resistant (Fig. 4) HeLa cells 2 days after infection with large inoculum of ECHO virus, Type 1. Parental HeLa completely destroyed and detached from glass. Resistant HeLa shows a definite area of damage but with large remaining areas of normal cells.

Figs. 5-6. Cultures of parental (Fig. 5) and resistant (Fig. 6) HeLa cells 2 days after infection with large inoculum of ECHO virus, Type 2. Parental HeLa; marked cellular destruction but some groups of cells remaining intact. Resistant HeLa; same as control uninoculated cells.

Figs. 7-8. Cultures of parental (Fig. 7) and resistant (Fig. 8) $\mathrm{HeLa}$ cells 2 days after infection with large inoculum of ECHO virus, Type 3. Parental HeLa; complete destruction. Resistant $\mathrm{HeLa}$; rounding and shrinkage of some cells and others thinning and elongation.

Figs. 9-10. Cultures of parental (Fig. 9) and resistant (Fig. 10) HeLa cells 2 days after infection with large inoculum of ECHO virus, Type 5. Parental HeLa; marked cellular destruction with remaining areas of normal cells. Resistant HeLa ; same as control uninoculated cells.

Figs. 11-12. Cultures of parental (Fig. 11) and resistant (Fig. 12) HeLa cells 2 days after infection with large inoculum of ECHO virus, Type 6. Parental HeLa; completely destroyed. Resistant HeLa ; slight damage, specificity doubtful.

Figs. 13-14. Cultures of parental (Fig. 13) and resistant (Fig. 14) HeLa cells 2 days after infection with large inoculum of ECHO virus, Type 9. Parental HeLa; irregular clusters of degenerating cells involving intact altered cells. Resistant HeLa; shrinkage and nuclear pyknosis of several cells, specificity doubtful.

Figs. 15-16. Cultures of parental (Fig. 15) and resistant (Fig. 16) HeLa cells 2 days after infection with large inoculum of Mahoney strain of poliovirus, Type 1. Marked cell destruction and detachment are seen in both HeLa cultures.

Figs. 17-18. Cultures of parental and resistant HeLa cells 4 days after infection with large inoculum of GI-67 strain of adeno virus, Type 4. Separation, rounding and clumping of cells are shown in both HeLa cultures. 


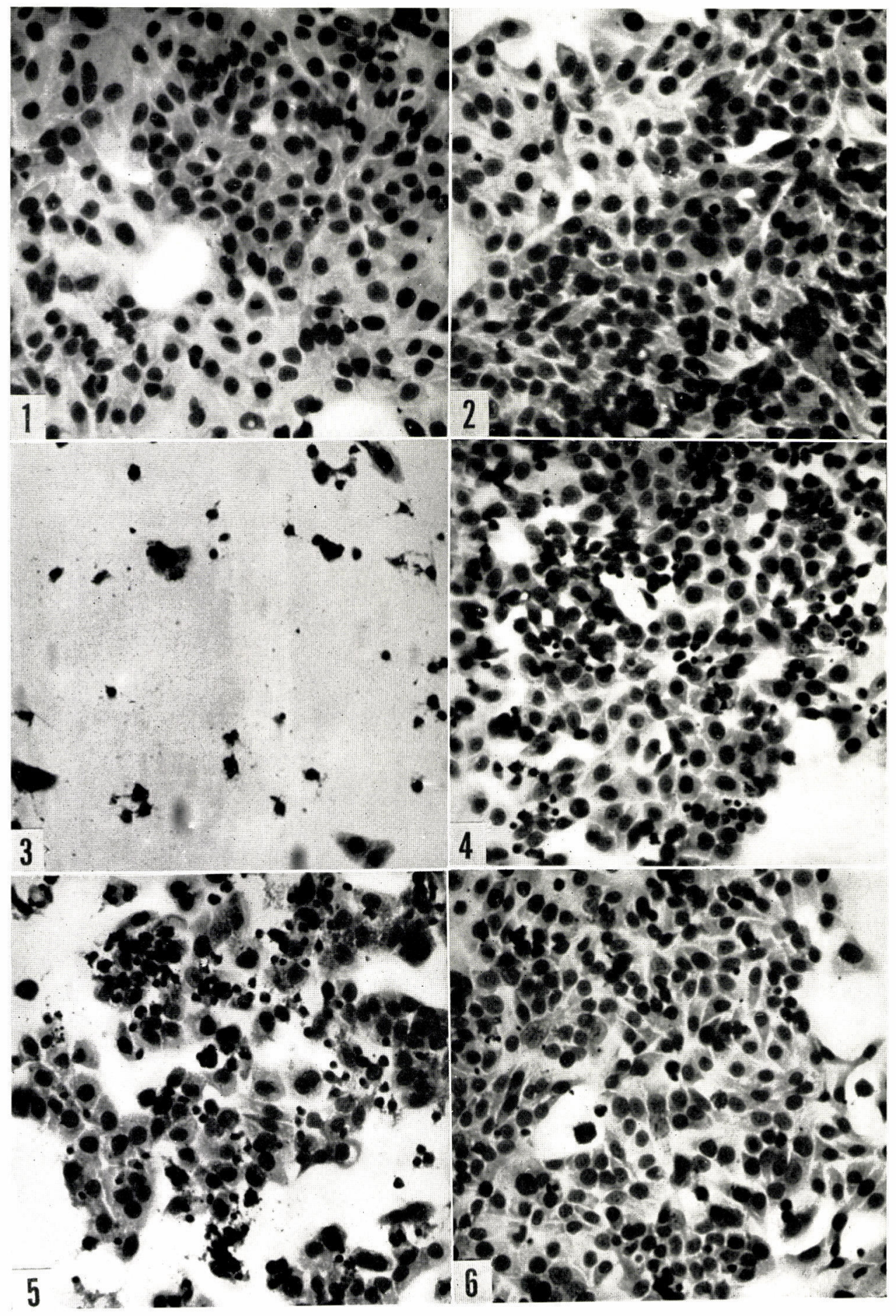




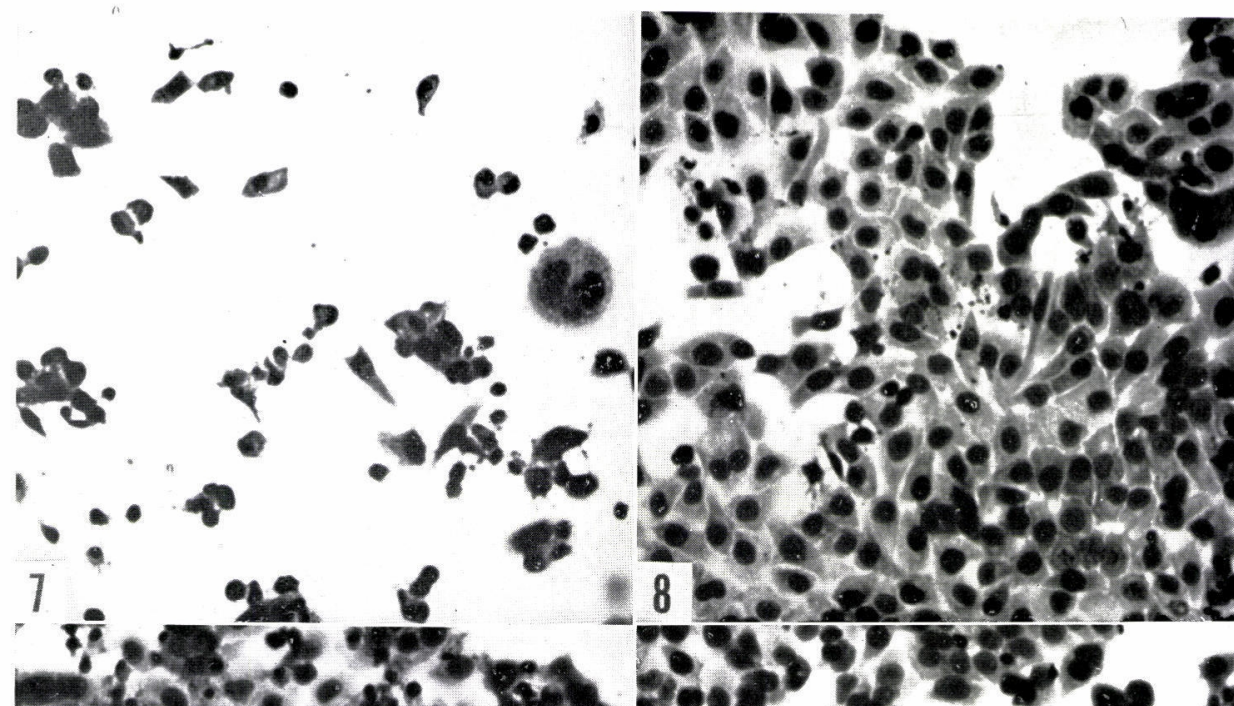
cos.

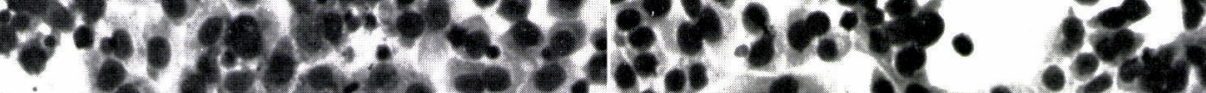

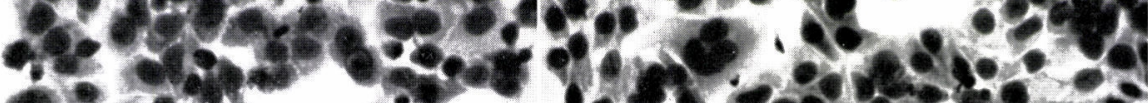
F-

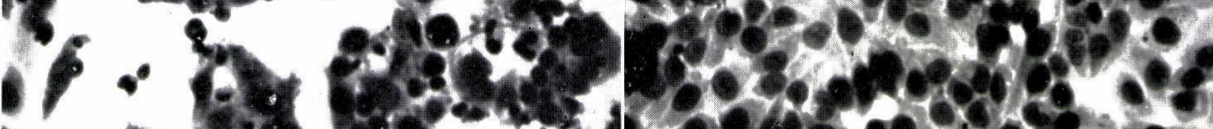

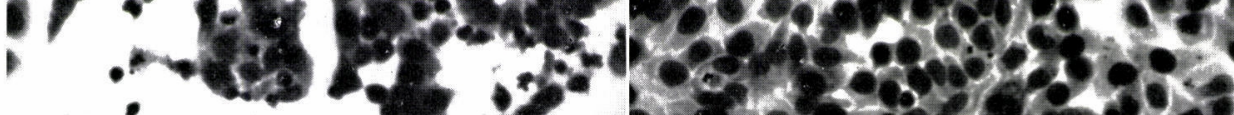

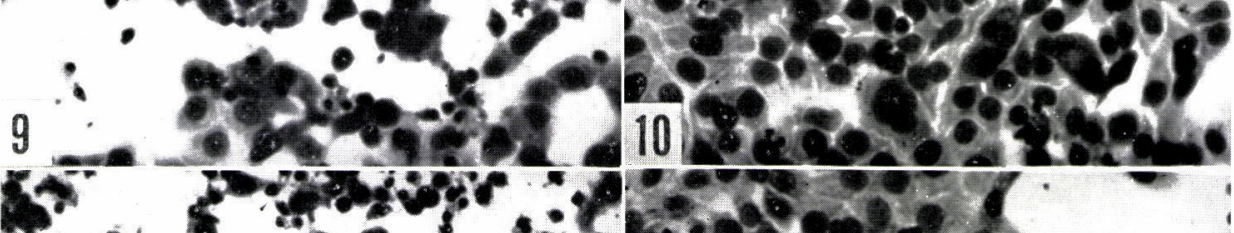
rost of

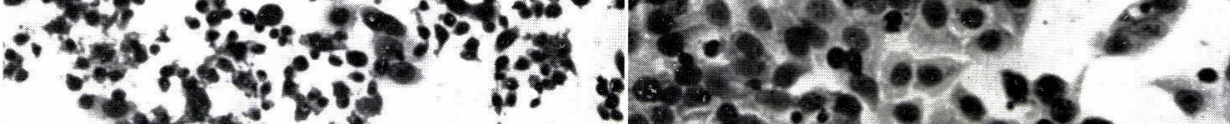

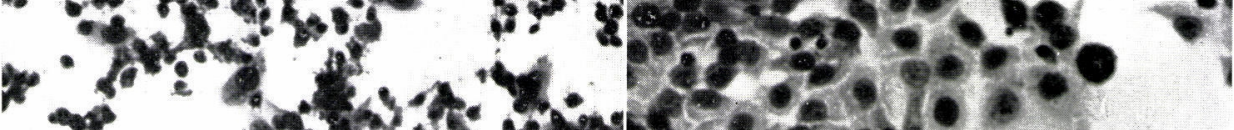

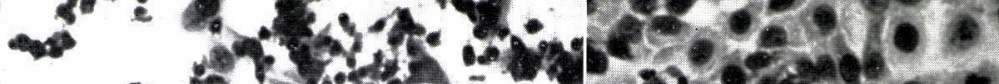

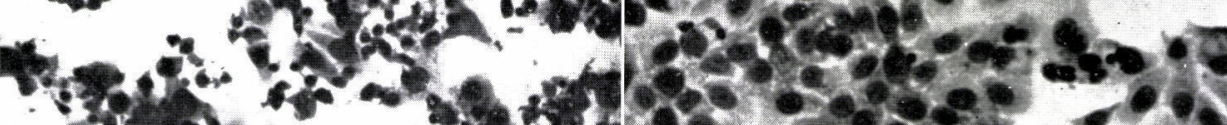

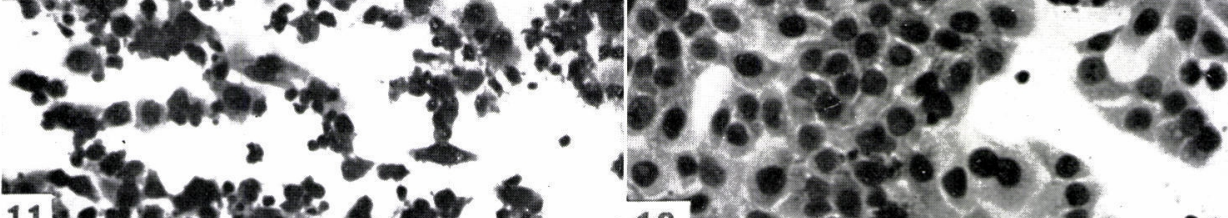

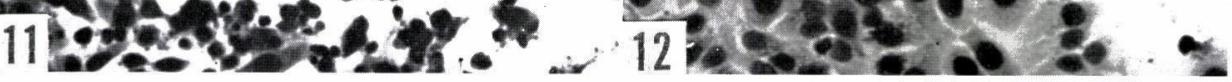




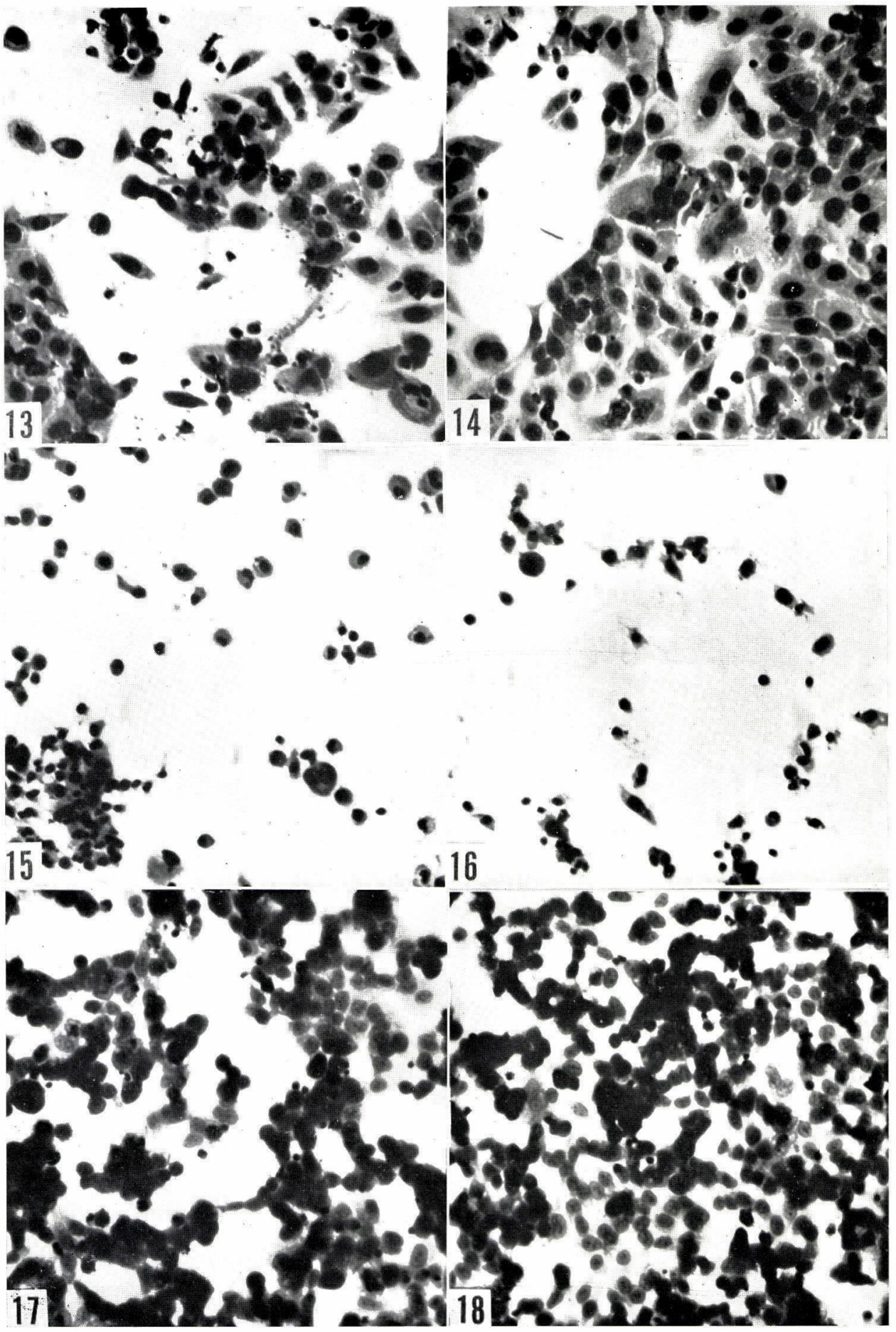

